\title{
Estimated Morbidity in the United States
}

\section{Based on Monthly Labor Force Report}

PHiLIP E. eNterline, Ph.D., and William H. SteWARt, M.D.

GINCE 1943 the U.S. Bureau of the Census $\$$ has been conducting monthly interviews of a representative sample of the noninstitutionalized civilian population of the United States. The primary purpose of these interviews is to obtain estimates of the total labor force, employment, unemployment, and number of workers outside the labor force.

Starting in July 1947 estimates have been published monthly of the number of employed persons 14 years of age and over who did not work at all the week preceding an interview because they were ill $(1, \mathscr{Z})$. This is the longest continuous series of estimates on illness available for the United States. The magnitude of the sample interviewed permits rather detailed comparisons of reported illness with social and demographic data. From July 1947 until May 1956 , a total of about 21,000 households were interviewed each month. Starting in May 1956 the number was increased to 35,000 households. It is the purpose of this paper to evaluate these data.

In judging data relating to illness it is important to keep in mind the distinction between illness as a concept and the manner in which this concept is measured. A concept is simply an idea of what a thing in general should be. Any particular measure of a concept is most useful if it is known how the measure was derived and if these methods satisfy the requirements of the user. Illness data from the labor force survey represent responses to questions which are presented in the technical note at

Dr. Enterline is chief, Morbidity and Health Statistics Branch, Division of Public Health Methods. and Dr. Stewart is chief of the division. the end of the paper. These responses were obtained under conditions specified there and more fully in publications relating to the labor force survey (1-3).

It is not always easy to judge the usefulness of data by examining a necessarily limited description of the procedures by which the data were derived. It is not known, for example, how closely interviewers for the labor force survey followed the instructions provided to them, or to what extent respondent replies reflect situations as they actually existed. Some help in evaluation is provided if it is known whether data vary apparently in response to the same stimuli as other data designed to measure illness. This report will be devoted mainly to comparisons of illness data from the labor force survey with other data about illness in the United States.

\section{Illness Trends}

Figure 1 shows the percentage of the total noninstitutionalized employed civilian labor force found on each monthly survey not to have worked at all the week preceding the interview because of illness. Also shown is a 12-month moving average. The monthly percentage reported not working because of illness generally ranged between 1 and 2 percent during the period July 1947 through September 1959, with rates in excess of 2 percent occurring only in February 1953, and October and November 1957. The 12-month moving average shows no overall trend, although the general level of illness appears to have been somewhat lower during the period 1949 through 1954 than in other years. 
A series on illness with which these data can be compared relates to the Armed Forces. This series shows the average daily proportion of total manpower unavailable for duty during each month because of illness $(4-6$ and personal communications from Dr. Wilbur V. Charter, Bureau of Medicine and Surgery, U.S. Navy, and Eugene Hamilton, Medical Statistics Division, U.S. Army). In the table and in figure 2, these data are compared with data derived from the labor force survey for the employed civilian labor force. Monthly data are available for the Air Force and the Navy only since July 1949.

Prior to 1955 the prevalence of illness in the Armed Forces, particularly in the Army, was relatively high, possibly reflecting some effect of the Korean conflict. The high prevalence of illness in the Army during 1947 and 1948 was apparently an aftermath of World War II.

Starting in 1955, the trends and fluctuations in rates are similar for all four series of data. Also starting in 1955, the general level of illness for the Armed Forces was similar to the level of illness in the civilian labor force series. Since the latter refers to illnesses mainly of a week's duration or longer, a somewhat lower rate might be anticipated. One reason for similar levels of illness may be that the civilian working population is older than the military, and illness tends to be positively associated with age; hence the age difference may partly offset the effects of the longer periods of illness to which the labor force data are limited.

\section{Seasonal Variation}

Figures 1 and 2 show very definite seasonal variations in the prevalence rate for illness in the employed civilian labor force. These seasonal variations tally quite well with those appearing in data for the Armed Forces, as is shown on figure 2, with a peak appearing in February and with relatively low rates for June, July, and August. They also tally well with other data available for civilian populations. In a study of illness in Baltimore for the years 1938-43, with visits at regular monthly intervals by interviewers experienced in morbidity surveys, the prevalence rate for persons disabled by illness on the day of the visit was found to be highest in February and lowest during the summer months $(y)$.

Starting in May 1955, data have been collected each month in the labor force survey on persons 14 years of age and over working parttime (less than 35 hours) the week preceding the interview because of illness. (Since July 1959, these data have been published monthly by the Department of Labor in Employment and Earnings, table A-16). The addition of these data to estimates of the number of employed persons 14 years of age and over who did not work at all the week preceding the interview because they were ill provides an estimate of all illness causing work loss in the civilian labor force.

Figure 3 shows the percentage of the employed civilian population absent on an average day because of illness during each quarter in the period July 1955 through September 1959 . Starting with the third quarter of 1957 , estimates derived from the labor force survey are compared with estimates from the National Health Survey ( 8 and unpublished data). Seasonal variations are quite similar in these two series. Starting in the summer of 1958, the prevalence of illness is also quite similar.

It is not certain why estimates from the labor force survey are appreciably lower than those from the National Health Survey during the fall of 1957 and the spring of 1958. The National Health Survey was a new activity in 1957, and it is possible that its newness was somehow associated with these higher reported rates of illness. There are many methodological differences between the two surveys which could be responsible for differing results. The purpose of the comparison in figure 3 was mainly to see if seasonal variations in illness reported in the labor force survey are generally consistent with those observed in a study of the civilian population of the United States designed more specifically to measure illness.

\section{Deviations From Expected Rafes}

Figure 4 shows for the labor force survey the difference between the observed monthly prevalence of employed persons reported not working at all the week preceding the interview because of illness, and an expected monthly 
Figure 1. Prevalence of illness in the employed civilian labor force resulting in work loss of a week or more, by month, July 1947-September 1959

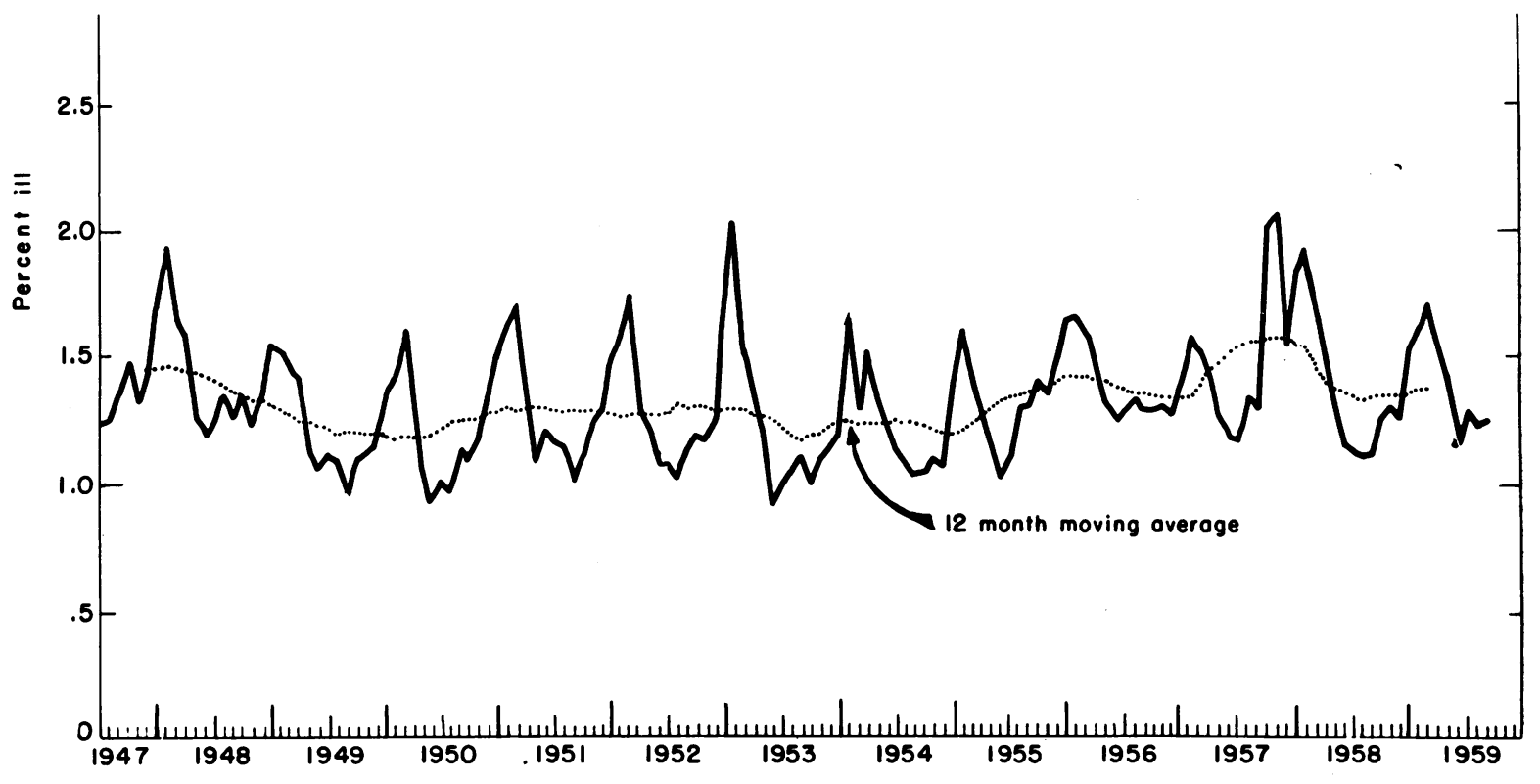

Figure 2. Prevalence of illness in the Armed Forces resulting in excuse from duty of a day or more, and in the employed civilian labor force resulting in work loss of a week or more, by month, July 1947-September 1959
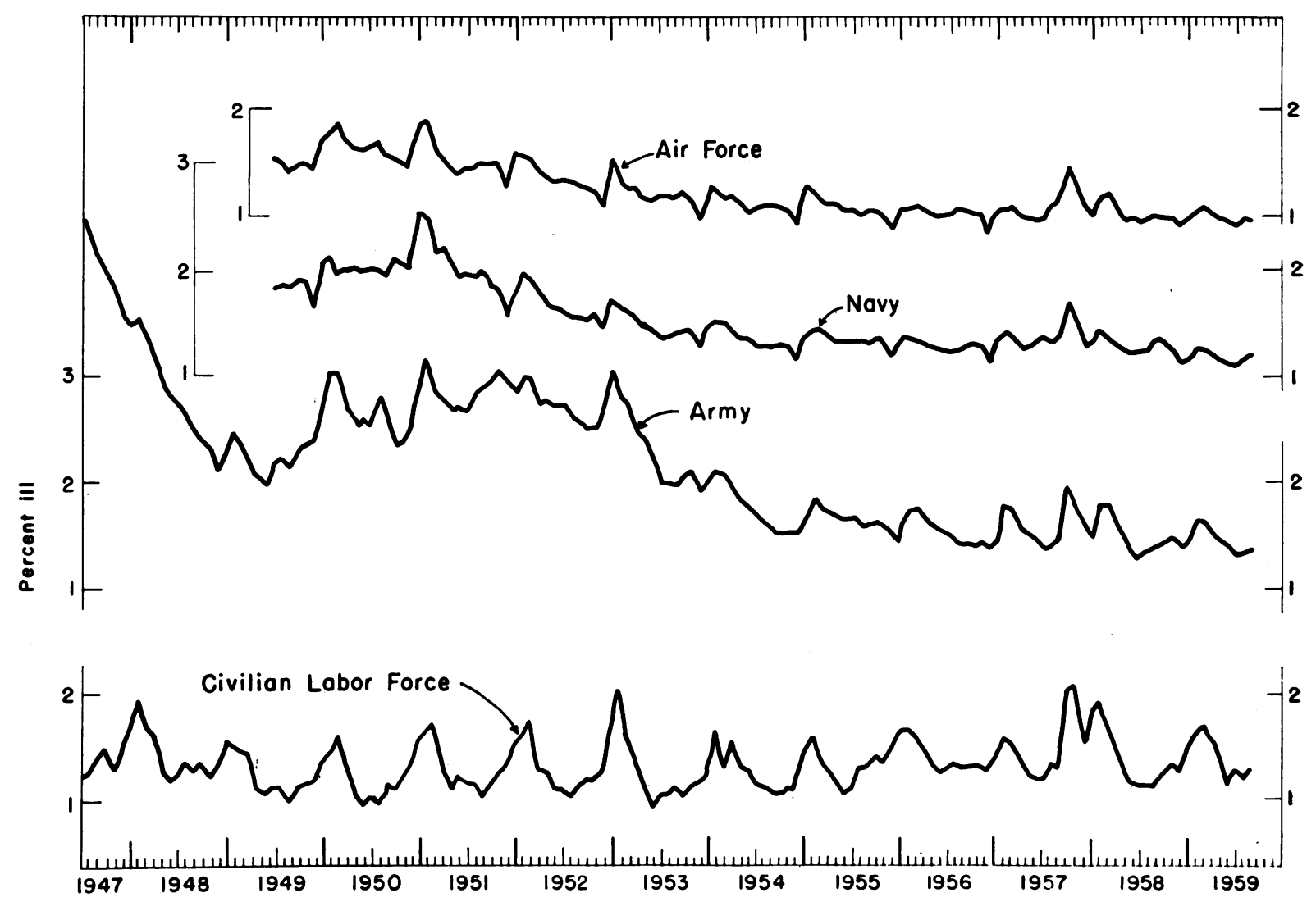
Prevalence of illness in the employed civilian labor force resulting in work loss of a week or more, and in the Armed Forces resulting in excuse from duty of a day or more, by month, July 1947September 1959

\begin{tabular}{|c|c|c|c|c|c|c|c|c|c|}
\hline \multirow[b]{2}{*}{ Month and year } & \multirow{2}{*}{$\begin{array}{l}\text { Employed } \\
\text { civilian } \\
\text { labor force } \\
\text { (percent) }\end{array}$} & \multicolumn{3}{|c|}{ Armed Forces } & \multirow[b]{2}{*}{ Month and year } & \multirow{2}{*}{$\begin{array}{l}\text { Employed } \\
\text { civilian } \\
\text { labor force } \\
\text { (percent) }\end{array}$} & \multicolumn{3}{|c|}{ Armed Forces } \\
\hline & & $\begin{array}{c}\text { Air } \\
\text { Force } \\
\text { (per- } \\
\text { cent) }\end{array}$ & $\begin{array}{l}\text { Navy } \\
\text { (per- } \\
\text { cent) }\end{array}$ & $\begin{array}{l}\text { Army } \\
\text { (per- } \\
\text { cent) }\end{array}$ & & & $\begin{array}{c}\text { Air } \\
\text { Force } \\
\text { (per- } \\
\text { cent) }\end{array}$ & $\begin{array}{l}\text { Navy } \\
\text { (per- } \\
\text { cent) }\end{array}$ & $\begin{array}{l}\text { Army } \\
\text { (per- } \\
\text { cent) }\end{array}$ \\
\hline 194 & & & & & 19 & & & & \\
\hline $\begin{array}{l}\text { July } \\
\text { August }\end{array}$ & 1. 23 & $(1)$ & (1) & 4. 52 & August & .97 & 1. 69 & 2. 00 & 2. 80 \\
\hline $\begin{array}{l}\text { August } \\
\text { Septemb }\end{array}$ & & (1) & (1) $^{(1)}$ & 4. & Sep & 1. 14 & 1. 57 & 1. 95 & 2. 63 \\
\hline & 1. 36 & $(1)$ & (1) & 4. & October- & 1.09 & 1.51 & 2. 11 & 2. 37 \\
\hline No & 132 & $\begin{array}{l}(1) \\
(1)\end{array}$ & $\begin{array}{l}(1) \\
(1)\end{array}$ & 3. & $\begin{array}{l}\text { Novembe } \\
\text { Decembe }\end{array}$ & $\begin{array}{l}\text { 1. } 18 \\
\text { 1. } 34\end{array}$ & $\begin{array}{l}1.50 \\
1.44\end{array}$ & $\begin{array}{l}2.06 \\
2.01\end{array}$ & $\begin{array}{l}2.39 \\
2.54\end{array}$ \\
\hline December & 1. 43 & (1) & (1) & 3. 57 & Decentis & & & & \\
\hline $1 s$ & & & & & January & 1. 55 & 1. 83 & 2. 54 & 2. 88 \\
\hline January & 1. 70 & (1) & (1) & 3. 50 & Feb & 1. 63 & 1. 90 & 2. 48 & 3. 18 \\
\hline Febr & 1. 94 & (1) & (1) & & & & 1. 60 & & 9 \\
\hline & 1. 68 & (1) & (1) & 3. & & 1. 30 & 1. 53 & 2. 21 & 2. 79 \\
\hline & 1.5 & (1) & (1) & 3. & $\mathrm{M}$ & 1. 08 & 1. 45 & 2. 09 & 2. 67 \\
\hline & 1. 2 & (1) & (1) & 2. 9 & JuI & 1. 21 & 1. 38 & 1. 93 & 2. 71 \\
\hline & 1. 18 & (1) & (1) & 2. 8 & & 1. 17 & 1. 45 & 1. 97 & 2. 68 \\
\hline & 1. 24 & (1) & (1) & 2. & & 1. 15 & 1. 46 & 1. 94 & 2. 86 \\
\hline & 1. 3 & (1) & (1) & 2. & ber & 1. 01 & 1. 52 & 1. 99 & 2. 93 \\
\hline & & (1) & (1) & 2.4 & $\mathrm{O}$ & 1. 12 & 1. 49 & 1. 85 & 2. 97 \\
\hline & 1. 35 & (1) & (1) & 2 & $\mathrm{~N}$ & 1. 23 & 1. 49 & 1. 81 & 3. 05 \\
\hline & 1. 22 & (1) & (1) & 2. 32 & December. & 1. 28 & 1. 25 & 1. 56 & 2. 99 \\
\hline Decembe & 1. 32 & (1) & (1) & 2. 13 & & & & & \\
\hline & & & & & Janus & & 1.59 & 1. 78 & \\
\hline Janua & 1. 55 & (1) & (1) & 2.25 & & 1.58 & 1. 58 & 1. 99 & 3. 03 \\
\hline & & (1) & (1) & & & & 1. 53 & 1. 90 & \\
\hline & 1. 46 & (1) & (1) & 2.: & & 1. 30 & 1. 43 & 1. 77 & 2. 78 \\
\hline & 1. 42 & (1) & (1) & & & 1. 23 & 1. 39 & 1. 68 & 2. 77 \\
\hline & & (1) & (1) & & & & 1. 36 & & 2. 74 \\
\hline & 1. 06 & (1) & (1) & & J & & 1. 35 & 1. 62 & 2. 74 \\
\hline & 1. 11 & 1. 52 & 1. 82 & 2. & & & 1. 32 & 1. 57 & \\
\hline & 1. 10 & 1. 50 & 1.8 & & $\mathrm{~S}$ & 1. 12 & 1. 30 & 1. 56 & 2. 59 \\
\hline ber & 96 & 1. 41 & 1. 8 & 2. & & & 1. 28 & 1. 53 & 2. 54 \\
\hline & 1. 11 & 1. 49 & $1 . !$ & & & & 1. 23 & 1. & 2. 54 \\
\hline & 1.13 & 1. 50 & 1. 90 & 2. 34 & December & 1. 26 & 1. 12 & 1. 45 & 2. 67 \\
\hline December_. & 1. 15 & 1. 46 & 1.63 & 2. 36 & & & & & \\
\hline & & & & & 19 & & & & \\
\hline Janu\& & & & & & & & $\begin{array}{l}1.54 \\
1.34\end{array}$ & $\begin{array}{l}1.73 \\
1.66\end{array}$ & 3. 05 \\
\hline & $\begin{array}{l}1.00 \\
1.41\end{array}$ & 1. 84 & 2.1 & 3. & $\mathrm{M}_{\mathrm{i}}$ & & 1. 28 & 1. 61 & 2. 78 \\
\hline & 1. 61 & 1. 86 & 1. 9 & 3. & & 1. 38 & 1. 26 & 1. 54 & 2. 52 \\
\hline & 1. 35 & 1. 70 & 1. 99 & 2. & $\mathrm{M}$ & 1. 20 & 1. 19 & 1. 47 & 2. 45 \\
\hline & 1. 05 & 1. 63 & 2. & 2. 55 & & & 1. 17 & 1. 42 & 2. 27 \\
\hline & .93 & 1. 63 & 1. 98 & 2. 56 & & 1. 01 & 1. 18 & 1. 39 & 2. 07 \\
\hline & 1. 00 & 1. 67 & 2. 02 & 2. 52 & August & 1. 04 & 1. 18 & 1. 38 & 2. 04 \\
\hline
\end{tabular}

${ }^{1}$ Information not available.

SOURCE: References 1, 2, 4-6.

prevalence. The expected rate was derived by computing the mean monthly prevalence rates for the 12-year period July 1947-June 1959 as percentages of the grand prevalence rate for all months and all years, and applying these percentages to the mean rate for each year. The difference between the observed and the ex- pected monthly prevalence rates might be considered the "excess monthly prevalence rate," that is, the part of the rate not explainable by seasonal expectancies and trends in rates.

The effects of four previously noted influenza epidemics are apparently reflected in the labor force data: epidemics in March of 1950 
Prevalence of illness in the employed civilian labor force resulting in work loss of a week or more, and in the Armed Forces resulting in excuse from duty of a day or more, by month, July 1947September 1959-Continued

\begin{tabular}{|c|c|c|c|c|c|c|c|c|c|}
\hline \multirow[b]{2}{*}{ Month and year } & \multirow{2}{*}{$\begin{array}{c}\text { Employed } \\
\text { civilian } \\
\text { labor force } \\
\text { (percent) }\end{array}$} & \multicolumn{3}{|c|}{ Armed Forces } & \multirow[b]{2}{*}{ Month and year } & \multirow{2}{*}{$\begin{array}{c}\text { Employed } \\
\text { civilian } \\
\text { labor force } \\
\text { (percent) }\end{array}$} & \multicolumn{3}{|c|}{ Armed Forces } \\
\hline & & $\begin{array}{c}\text { Air } \\
\text { Force } \\
\text { (per- } \\
\text { cent) }\end{array}$ & $\begin{array}{l}\text { Navy } \\
\text { (per- } \\
\text { cent) }\end{array}$ & $\begin{array}{l}\text { Army } \\
\text { (per- } \\
\text { cent) }\end{array}$ & & & $\begin{array}{c}\text { Air } \\
\text { Force } \\
\text { (per- } \\
\text { cent) }\end{array}$ & $\begin{array}{l}\text { Navy } \\
\text { (per- } \\
\text { cent) }\end{array}$ & $\begin{array}{l}\text { Army } \\
\text { (per- } \\
\text { cent) }\end{array}$ \\
\hline 19 & & & & & & & & & \\
\hline September & 1. 11 & 1. 16 & 1. 42 & 2. 01 & October & 1. 31 & 1. 02 & 1. 28 & 1. 40 \\
\hline October & 1. 01 & 1. 22 & 1. 43 & 2. 09 & Novembe & 1. 31 & 1. 02 & 1. 28 & 1. 44 \\
\hline & 1. $1 \mathrm{I}$ & 1. 14 & 1. 44 & 2. 11 & December & 1. 29 & .84 & 1. 15 & \\
\hline December & 1. 15 & .98 & 1. 26 & 1. 94 & & & & & \\
\hline 1954 & & & & & January & 1. 40 & 96 & 1.28 & 1.43 \\
\hline January & 1.20 & 1. 27 & 1. 44 & 2. 05 & Fehruary & 1.58 & 1. 05 & 1. 40 & 1. 77 \\
\hline Febru & 1. 66 & 1. 23 & 1. 53 & 2. 11 & March_. & 1.53 & 1. 06 & 1.37 & 1. 75 \\
\hline Marc & 1.30 & 1. 18 & 1. 50 & 2.07 & April & 1. 39 & 1. 03 & 1. 29 & 1. 61 \\
\hline April & 1.53 & 1. 19 & 1. 42 & 1.98 & May & 1. 24 & .98 & 1.25 & 1.50 \\
\hline & 1. 32 & 1.14 & 1. 33 & 1. 84 & June- & 1. 18 & .97 & 1. 31 & 1. 43 \\
\hline June & 1. 26 & 1. 02 & 1. 31 & 1. 75 & July & 1. 18 & 96 & 1. 37 & 1. 37 \\
\hline July & 1.14 & 1. 06 & 1. 27 & 1. 69 & August & 1. 33 & 1.08 & 1. 32 & 1. 40 \\
\hline Augu & 1.08 & 1. 09 & 1. 28 & 1. 64 & Sep & 1. 30 & 1. 11 & 1. 38 & 1. 54 \\
\hline & 1.04 & 1. 09 & 1. 27 & 1. 54 & Oct & 2. 03 & 1. 44 & 1. 70 & 1.96 \\
\hline Octo & 1.05 & 1. 08 & 1. 30 & 1. 51 & November. & 2. 06 & 1. 29 & 1. 49 & 1. 74 \\
\hline November & 1. 09 & 1. 03 & 1. 29 & 1. 51 & December_ & 1. 54 & 1. 09 & 1. 29 & 1. 57 \\
\hline December.- & 1.08 & .92 & 1. 13 & 1. 51 & & & & & \\
\hline 1955 & & & & & Januar & & & & \\
\hline January .... & 1. 43 & 1. 30 & 1. 34 & 1. 66 & February & $\begin{array}{l}1.84 \\
1.94\end{array}$ & 1. 17 & $\begin{array}{l}1.51 \\
1.43\end{array}$ & $\begin{array}{l}1.00 \\
1.79\end{array}$ \\
\hline Febr & 1. 61 & 1. 22 & 1. 43 & & Mar & 1. 65 & 1. 20 & 1. 37 & 1. 78 \\
\hline Mar & 1.42 & 1. 17 & 1. 43 & 1. 77 & Apl & & 1. 07 & 1.31 & 1. 59 \\
\hline & 1. 27 & 1. 12 & 1. 39 & 1. 72 & $\mathbf{M}$ & 1. & .99 & 1.26 & 1. 44 \\
\hline May & 1.17 & 1. 12 & 1. 35 & 1. 69 & Jun & 1. 16 & .96 & 1. 24 & 1. 31 \\
\hline Jun & 1.03 & 1. 04 & 1. 35 & 1. 67 & Jul & 1. 14 & .94 & 1. 25 & 1. 29 \\
\hline & 1. 09 & 1. 04 & 1. 35 & 1. & & 1. 13 & .96 & 1. 25 & 1. 35 \\
\hline $\mathrm{Au}$ & 1. 30 & 1. 01 & 1. 34 & 1. 60 & ber. & 1. 14 & .98 & 1. 28 & 1.41 \\
\hline Sept & 1. 30 & 1. 03 & 1. 33 & 1. 62 & Octo & 1. 26 & .98 & 1. 28 & 1. 46 \\
\hline October--.- & 1. 40 & 1. 04 & 1. 36 & 1. 6 & November & 1. 31 & .98 & 1.26 & 1. 47 \\
\hline November - & 1. 36 & 1. 01 & 1. 36 & 1. 59 & December & 1. 25 & .90 & 1. 13 & 1. 40 \\
\hline December & 1. 49 & .85 & 1. 21 & 1. 46 & & & & & \\
\hline 1956 & & & & & January & 1. 52 & 97 & 1. 16 & 1. 48 \\
\hline January _. _ & 1. 64 & 1. 07 & 1. 29 & 1. 5 & Febr & 1. 61 & 1. 04 & 1. 27 & 1.66 \\
\hline Febr & 1.65 & 1. 07 & 1. 37 & 1. & March & 1. 70 & 1. 06 & 1. 26 & 1.65 \\
\hline Marc & 1.57 & 1. 09 & 1. 34 & 1.7 & Apri & 1. 57 & 1. 04 & 1. 22 & 1. 54 \\
\hline April... & 1. 43 & 1. 06 & 1. 32 & 1.6 & & 1. 39 & .96 & 1. 17 & 1. 46 \\
\hline$\ldots$ & 1. 32 & .98 & 1. 28 & 1. & & & .94 & 1. 13 & 1. 40 \\
\hline June & 1. 25 & .99 & 1. 25 & 1. & Julv & & 92 & 1.12 & 1.40 \\
\hline July & 1. 28 & 1. 00 & 1. 24 & 1. 50 & August & 1. 23 & .96 & 1. 17 & $\begin{array}{l}1.01 \\
1.34\end{array}$ \\
\hline & 1. 33 & 1. 02 & 1. & 1.4 & September & 1. 27 & .95 & 1. 19 & 1. 35 \\
\hline September & 1.30 & 1. 04 & 1. 25 & 1. 4 & & & & & \\
\hline
\end{tabular}

and 1951 and in February of 1953 (9), and the Asian influenza epidemic in October and November of 1957 (10). Some of the periods of excess prevalence of illness shown in figure 4 are apparently not associated with influenza epidemics. On the other hand, an epidemic in the spring of 1958, reported by Dauer (10), does not appear in figure 4 . The failure of the 1958 epidemic to appear in the chart is due largely to the inclusion of epidemic rates in the data from which expected rates were computed.

A refinement of the data shown in figure 4 is shown in figure 5. Here, the effects of the epidemics have been removed from the expected rates by substituting rates observed in the same month for the preceding nonepidemic year. For March 1950 and March 1951 the rate observed for March 1949 was substituted; for 
February 1953 the rate observed for February 1952 was substituted; and for October 1957 through March 1958 the rates observed for October 1956 through March 1957 were substituted. In addition, for figure 5 the adjustment for trend was made quarterly rather than annually as in figure 4. This removes some cyclical movement apparently due to trends in the overall illness level. The method used in computing a normal seasonal curve for illness was essentially the one used by Collins and Lehmann in computing a normal seasonal curve for deaths from influenza and pneumonia (9). The base period for the illness data is the entire 12 years for which data were available.

Weekly excess mortality from influenza and pneumonia is also shown in figure 5. Data previously reported for the period July 1947 through June 1956 (9) have been carried through June 1959. The base period for July
1956 through June 1959 is the 5 years ending in August 1955.

The epidemic of Asian influenza in the spring of 1958 shows clearly in the labor force data plotted in figure 5, corresponding to an excess in mortality from influenza and pneumonia noted during that period. Generally, influenza epidemics, as measured by excess mortality from influenza and pneumonia, are reflected quite well in labor force illness data. There are, however, some periods of excess prevalence of illness which may be due to influenza but which are not associated with excess mortality. Both mortality and illness data suggest that the effects of influenza have increased since 1947.

Starting in 1954 , the pattern of fluctuations in the prevalence of illness in the labor force survey series shown in figures 4 and 5 differs somewhat from the pattern for prior years,

Figure 3. Percent of employed civilian labor force absent on an average workday because of illness as estimated from labor force survey data, and National Health Survey data, by quarter, July 1955-September 1959

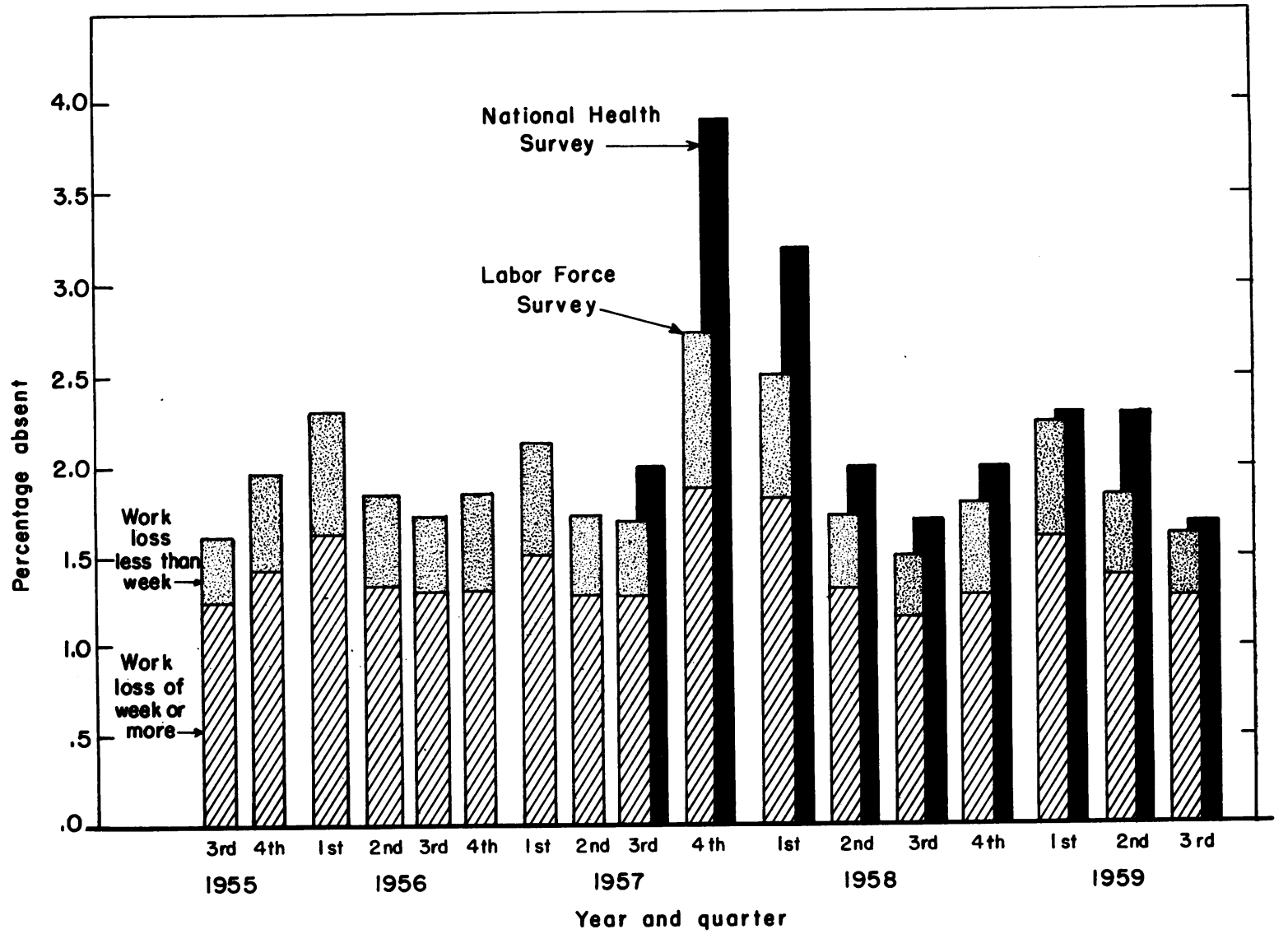


Figure 4. Monthly excess prevalence of illness in the employed civilian labor force resulting in work loss of a week or more, July 1947-June 1959

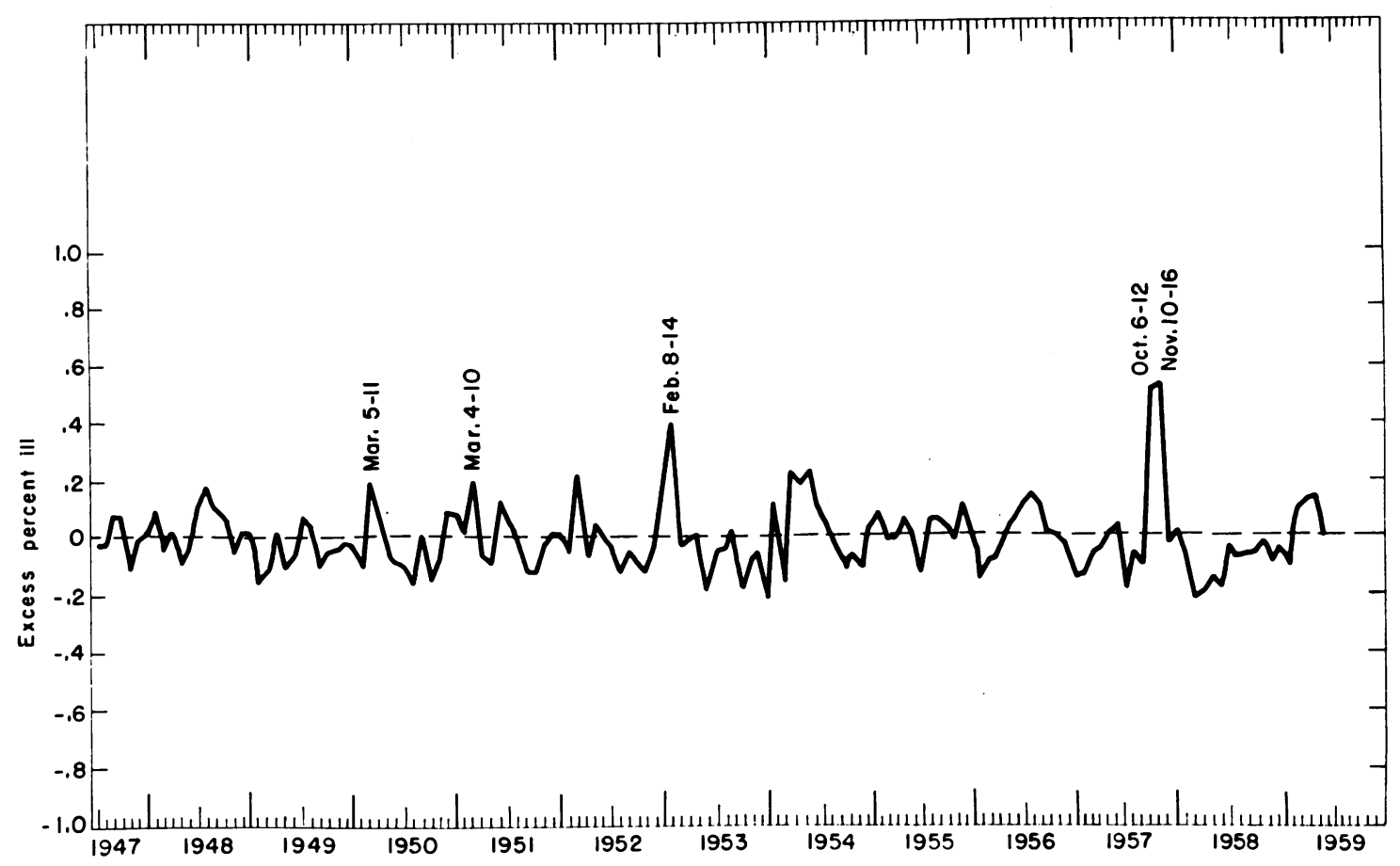

Figure 5. Monthly excess prevalence of illness in the employed civilian labor force resulting in work loss of a week or more (with influenza epidemics removed from expected rates), and weekly excess mortality from influenza and pneumonia in groups of cities in the United States

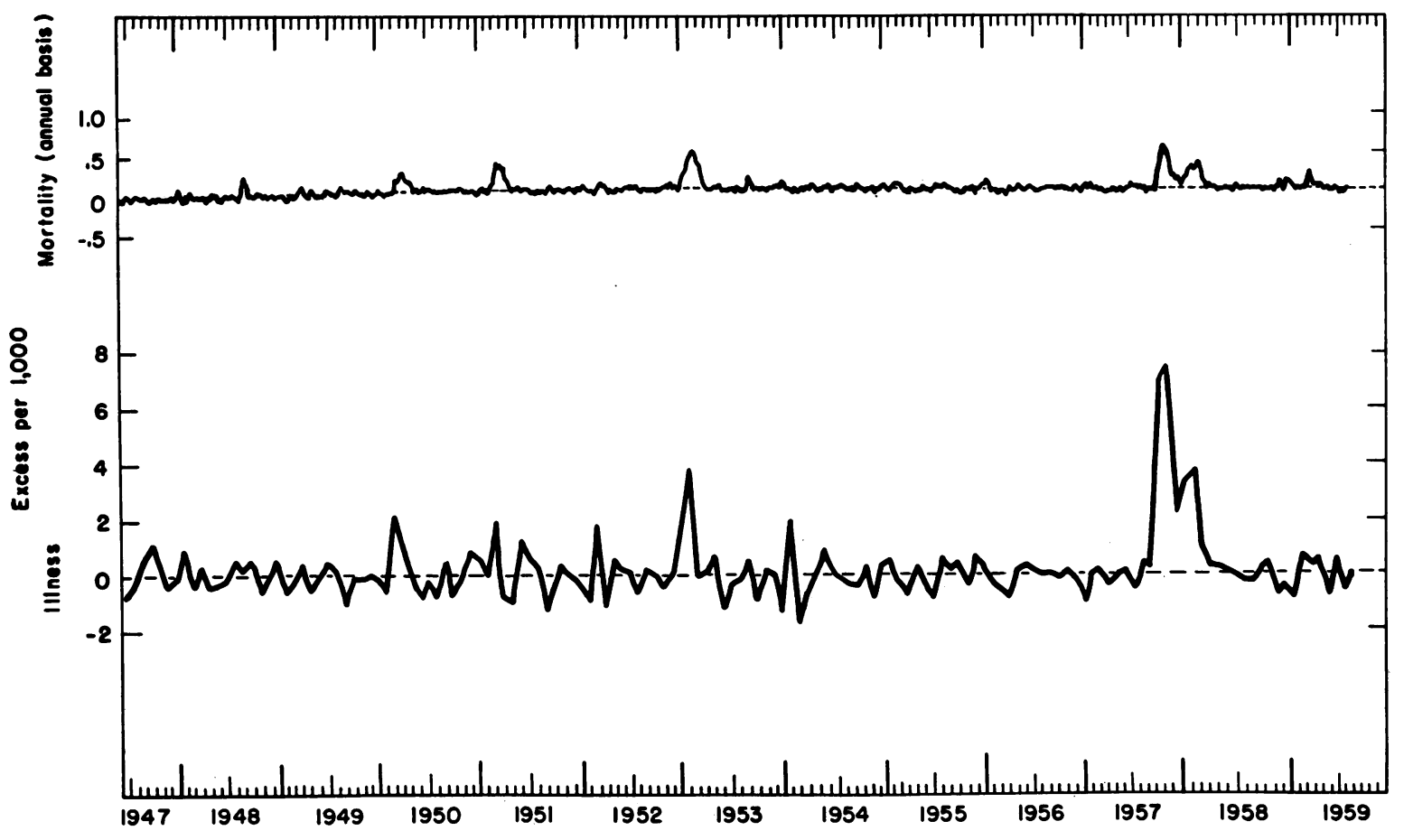


tending to move more systematically from one month to the next. This may be due to an expansion of the labor force sample from a 68-area sample to a 230-area sample in February 1954. Although the number of households interviewed each month did not change, the increase in the numbers of areas sampled, coupled with a substantially improved estimation procedure, increased the reliability of most of the major statistics by an amount equivalent to doubling the sample size (3).

\section{Conclusion}

For many purposes, the framework within which the presence of illness is established in the labor force survey would seem favorable to a fairly meaningful interpretation. For the series starting in July 1947, the type of illness dealt with is probably moderately severe, requiring the loss of a full week's work, or more, for persons otherwise economically active. It is not so severe, however, as to prevent employment. It is illness defined in a particular and possibly peculiar way.

The illness measured by the labor force survey apparently responds to many of the same factors as other measures of illness. Probably chief among these is influenza. In view of the large amount of data routinely accumulated by the monthly survey of the labor force and the general acceptance of its definitions of common occupational and economic variables, further examination of tabulated as well as untabulated materials would seem to be a valuable adjunct to other currently available measures of illness in the United States.

\section{Summary}

Starting in July 1947, estimates have been published in "The Monthly Report on the Labor Force" showing the total employed persons in the civilian labor force 14 years of age and over, and the number of these persons who did not work at all the week preceding a monthly interview because they were ill.

During the period July 1947 through September 1959, the percentages of ill persons ranged between 1 and 2 percent. No overall trends are apparent.
Fluctuations in these illness rates generally conform to fluctuations observed in illness rates for the Armed Forces; seasonal variations conform to those observed in illness surveys of civilian populations and to seasonal variations in Armed Forces data.

Influenza epidemics noted in studies of mortality are clearly shown in the labor force series.

Generally, information on illness reported in "The Monthly Report on the Labor Force" would seem to be a valuable supplement to other data regarding illness patterns and trends in the United States.

\section{TECHNICAL NOTE}

\section{Definitions}

Employed civilian labor force. "The Monthly Report on the Labor Force" includes in the employed civilian labor force all civilians who, during a specified week: ( $a$ ) did any work at all as paid employees or in their own businesses or professions, or on their own farms, or worked 15 hours or more as unpaid workers on a farm or in a business operated by a member of their families; or (b) were not working or looking for work but had jobs or businesses from which they were temporarily absent because of illness, bad weather, vacation, or labor-management dispute, or because they were taking time off for various other reasons.

The National Health Survey identifies the civilian population "usually working." This population, while similar, is not identical to the employed civilian labor force as defined in "The Monthly Report on the Labor Eorce."

Illness. As used here, and as the concept of illness applies to the working population, illness data are intended to include all persons not working because of medical reasons, including sickness, injuries, or ill effects from earlier accidents or injuries. This concept is implied in data published in "The Monthly Report on the Labor Force" and specified in data published for the Armed Forces and by the National Health Survey.

\section{Measurement of Illness}

Labor force survey. Illness lasting an entire workweek is identified for each person 14 years of age and over from the following series of questions :

"Did __ do any work at all last week, not counting work around the house?" If "No" :

"Was _ looking for work?" If "No" :

"Even though __ did not work last week, does he have a job or business?" If "Yes" :

"Why was he absent from work last week?"

Answers to the last question fall mainly into four categories : own illness, on vacation, bad weather, and 
labor dispute. The illness prevalence rate for a single month is the proportion of the enumerated employed civilian labor force who reported that they did no work during the entire week preceding the enumeration because of own illness.

Illness lasting less than a workweek is identified for each employed person 14 years of age and over who worked less than 35 hours the week prior to the interview, from the following series of questions :

"Does_usually work 35 hours or more a week at this job?" If "Yes":

"What is the reason worked less than 35 hours last week?"

One category of response to the last question is "own illness." In order to derive the prevalence rates shown in figure 3 , it was necessary to estimate the average number of days of absence for persons absent less than 1 workweek. This was estimated at 2.54 days, based on a study by Gafafer and Frasier (11). Workdays were estimated as 260 per person per year.

Each month's illness figures represent a single week's experience for the employed civilian labor force. Prior to July 1955, published figures were for the calendar week containing the eighth day of the month. In July 1955, this was changed to the calendar week containing the 12th day of the month.

Armed Forces. In the Armed Forces, illness is identified from reports on persons not available for duty for medical reasons. The Air Force includes in the illness category persons under treatment as inpatients, in quarters, on sick leave, or AWOL from a patient status for 10 days or less. The Army includes excused-from-duty patients in hospitals and quarters in all medical-treatment facilities. The illness prevalence rate for a single month is the proportion of the available man-days lost because of illness, that is, the average daily proportion of the average total manpower unavailable for duty because of illness. This prevalence rate is usually referred to as the noneffective rate or ratio and is a principal measure of manpower loss due to medical causes or injury used by the Armed Forces.

Data for the Air Force and Navy are worldwide. Data for the Army are for the continental United States only, but include evacuees. Air Force data are for all medical causes while Navy and Army data exclude battle injuries.

National Health Survey. In the National Health Survey, illness is identified for the "usually working" population 17 years of age and over by first attempting to identify for the 2-week period preceding the interview sickness, accidents or injuries, ill effects from earlier accidents or injuries, and medicine or treatment taken. Also, an attempt is made to identify the presence of "ailments or conditions that have continued for a long time" and a "yes" or "no" response is obtained to a checklist of 35 chronic conditions and impairments. If any illness (disease, impairment, accident, etc.) is identified in any of these screening questions and it is established that the illness caused the individual to cut down on his usual activities for as much as a day, the question is asked: "Last week or the week before, would you have been working at a job or business except for (the condition named)? How many days [during last week or the week before] did (the condition named) keep you from work?"

The illness prevalence rate for any period of time is the proportion of available man workdays lost because of illness. In this report, available man workdays were estimated as 260 per person per year.

\section{Standard Error of Labor Force Estimates}

The estimates of the prevalence of illness in the civilian employed labor force are based upon a sample and may differ somewhat from figures which would have been obtained if a complete census had been taken. The following table gives a rough idea of the order of magnitude of the standard error of the estimated prevalence rates shown for each month, beginning in February 1954. The chances are about 68 out of 100 that an estimate for a single month would differ from a complete census by less than the standard error.

Standard error of labor force illness prevalence rates

\begin{tabular}{|c|c|c|}
\hline \multirow{2}{*}{ Percentage ill } & \multicolumn{2}{|c|}{ Standard error of estimate } \\
\hline & $\begin{array}{c}\text { February } \\
\text { 1954-April } \\
1956\end{array}$ & $\begin{array}{c}\text { May } 1956- \\
\text { September } \\
\quad 1959\end{array}$ \\
\hline 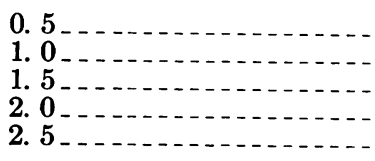 & $\begin{array}{r}0.053 \\
.074 \\
.092 \\
.104 \\
.114\end{array}$ & $\begin{array}{r}0.042 \\
.059 \\
.073 \\
.082 \\
.091\end{array}$ \\
\hline
\end{tabular}

\section{REFERENCES}

(1) U.S. Bureau of the Census: The monthly report on the labor force. Current Population Reports, Series P-57. Washington, D.C., U.S. Government Printing Office, each month, July 1947-June 1959.

(2) U.S. Department of Labor: The monthly report on the labor force. Washington, D.C., July, August, September, 1959.

(3) U.S. Bureau of the Census : Concepts and methods used in the current employment and unemployment statistics prepared by the Bureau of the Census. Current Population Reports, Series P-23, No. 5. Washington, D.C., U.S. Government Printing Office, May 9, 1958.

(4) U.S. Air Force, Office of the Surgeon General: Annual report of the USAF Medical Service. Each year, 1949-1959.

(5) U.S. Navy, Bureau of Medicine and Surgery: Statistics of Navy medicine. Each month, January 1955-December 1959. 
(6) U.S. Army, Office of the Surgeon General: Health of the Army. (Selected issues.)

(y) Collins, S. D.: A review and study of illness and medical care. PHS Pub. No. 544 (Pub. Health Monogr. No. 48). Washington, D.C., U.S. Government Printing Office, 1957, p. 59.

(8) U.S. National Health Survey: Disability days. PHS Pub. No. 584-B10. Washington, D.C., U.S. Government Printing Office, 1959, p. 41.

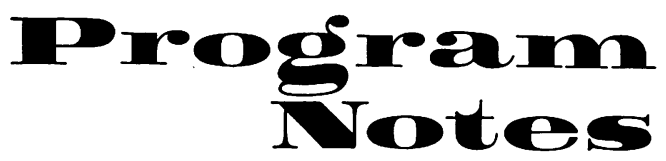

\section{The Personal Touch}

Enlistment of the cooperation of physicians in many public health programs is frequently difficult. This is not in any sense due to their perversity or lack of interest, but is related more to lack of emphasis on public health teaching when many physicians attended medical school.

The need for physician cooperation became evident in the tuberculosis control program of the Boston Health Department. Here it was a question of alerting physicians in high incidence areas to the frequency of diagnoses of tuberculosis in their areas, and emphasizing the services available to them in the Boston Health Department for the diagnosis, treatment, and followup of cases. The health department had sent letters giving physicians this information, but it was impossible to evaluate their effectiveness. It was thought advisable to extend this educational program.

Personal interviewing of the physicians of Boston to call to their attention the public health aspects of tuberculosis control was the course selected. Greatest emphasis is placed on contacts with physicians who practice in areas where tuberculosis incidence is highest, with efforts in the areas of lesser incidence determined by personnel time available for the program. Two health educators from the department and two from the Boston Tuberculosis Association were made available.

Information concerning tuberculosis control presented to the physicians at pre-arranged visits to their offices include:
(9) Collins, S. D., and Lehmann, J. L.: Influenza epidemics during 1951-56, with a review of trends. Pub. Health Rep. 72: 771-780, September 1957.

(10) Dauer, C. C. : Mortality in the 1957-58 influenza epidemic. Pub. Health Rep. 73: 803-810, September 1958.

(11) Gafafer, W. M., and Frasier, E. S.: Studies on the duration of disabling illness. Pub. Health Rep. 57: 1378-1384, Sept. 11, 1942.

- Statistics on the incidence of tuberculosis in Boston in general and in the specific area of practice.

- Schedules giving the times and locations where $\mathrm{X}$-ray, laboratory, and consultation services are available in the health department for private patients, stressing that the results of these examinations are reported only to the referring physician who retains the private care of the patient.

- Literature on the use of the Mantoux tuberculin test, its interpretation, and a detailed description of its technique, with a supply of $1: 2,000$ solution of O.T. provided on request.

- Detailed information on the rehabilitation services available to private patients.

They are given stickers to attach to prescription blanks authorizing $14^{\prime \prime} \times 17^{\prime \prime}$ chest X-rays of patients, the findings reportable only to the prescribing physician, and bottles for use in sending specimens of sputum of patients to the department for analysis for tubercle bacilli by smear or culture. They are also informed that sensitivity testing is available upon request.

Questions are answered and physicians are asked for any suggestions or criticisms, either on health department practices in general or the tuberculosis program in particular.

The interviewers have been very well received. Of 111 physicians visited, only 2 were not interested and only 1 showed annoyance. Double postcards for followup of these interviews were returned by 50 percent of the physicians visited. Of the physicians who returned postcards, over 95 percent were enthusiastic and stated that they would like additional visits at intervals of about a year.-GEORGE KAHN, M.D., M.P.H., chief, bureau of disease control, Boston Health Department. 